\title{
Oral anticoagulation after isolated aortic valve replacement
}

\author{
Ivana Burazor \\ Cardiology Department, Institute for rehabilitation, Belgrade, Serbia
}

Abstract Aortic stenosis is the most common primary valve disease leading to surgery or catheter intervention in Europe and North America, with a growing prevalence due to the ageing population. In this case report we present case of a patient who was referred to our cardiology department for in-patient exercise based cardiac rehabilitation after isolated aortic valve replacement and who was treated successfully with special emphases on anticoagulant therapy choice and patient education. Novel oral anticoagulant was replaced with VKA according to guidelines.

Regarding oral anticoagulants, guidelines from both sides of the Atlantic ocean remain the same. Oral anticoagulation using a VKA is recommended lifelong for all patients with mechanical prosthesis! INR self-management is recommended. Target INR after mechanical prosthesis according the 2017 Guidelines will depend on prosthesis trombogenicity and patient related risk factors (mitral or tricuspid valve replacement, previous thromboembolism, atrial fibrillation, mitral stenosis any degree, LVEF $<35 \%$ ).

Key words Oral anticoagulants, aortic valve replacement, cardiac rehabilitation

\section{Introduction}

urrent guidelines from the European Society of Cardiology recommend exercise-based cardiac rehabilitation for patients after heart valve surgery, based on reviews of observational studies, and clinical expertise. After surgery, people are often immobilized due to hospitalization, possible post-surgery complications, and restrictions designed to assist healing of the sternum. Consequently, their physical capacity is at risk of additional decline. As open heart surgery can be an extraordinary and stressful life event (1), quality of life may be affected (2), with mental problems such as depressive symptoms and anxiety.

European guidelines for people after heart valve surgery recommend rehabilitation that includes exercise training, anticoagulant therapy, and medical and echocardiographic follow-up, but do not mention that psycho-educational interventions should be part of the rehabilitation programs (3). In contrast, American guidelines do not currently include any recommendations or information about cardiac rehabilitation after heart valve surgery, either exercise-based or including psychoeducation.

In this case report we present the case of a patients who was referred to our cardiology department for inpatient exercise based cardiac rehabilitation after aortic valve replacement and who was treated successfully with special emphases on anticoagulant therapy choice and patient education.

\section{Case presentation}

A 69-year-old woman was referred to our Cardiology department for in-patient three weeks cardiac rehabilitation program after isolated aortic valve replacement with mechanical prosthesis St Jude No 19.

\section{Patient assessment}

History of present illness and previous heart investigations

- In 2010 patient was diagnosed aortic valve stenosis and was followed up.

- In 2017 because of disease and symptoms progression, aortic stenosis was characterized echocardiographically and subsequently required mechanical aortic valve replacement according to guidelines (both ACC and ESC 2017).

- Coronary angiography showed no coronary artery stenosis. - The patient was scheduled for operative mechanical AV replacement through sternotomy.

- Postoperative TTE confirmed the adequate functioning of the extra-anatomically placed aortic prosthesis with the mean transvalvular gradient of $12 \mathrm{mmHg}$. Postoperative paroxysmal atrial fibrillation occurred on day 5 and was converted to sinus rhythm by using medications.

Past medical history:

- Hypertension

- Obesity

- Postoperative AF, medical conversion to sinus rhythm 
Social history: married, two children, non-smoker,

Physical activity level: poor, sedentary lifestyle, indoor activities, lives on $3^{\text {rd }}$ floor, no elevator

Home medication:

1. Dabigatran $150 \mathrm{mg}$ BID - given by Private Practice MD (reason: warfarin replaced due to poor INR control)

2. Amiodarone $1 \times 200 \mathrm{mg}$ (weekend break) OD - given by Private Practice MD ( Bisoprolol was replaced)

3. Lercandipine $10 \mathrm{mg}$ OD

4. Rosuvastatin $5 \mathrm{mg}$ OD

Vital signs on admission:

BP 170/100 $\mathrm{mmHg} \bullet$ Pulse 82/min • Temp 36,6 ${ }^{\circ} \mathrm{C} \bullet$ Resp $20 \bullet \mathrm{Ht}(1.65 \mathrm{~m}) \cdot \mathrm{Wt} 72 \cdot \mathrm{BMI} 27 \mathrm{~kg} / \mathrm{m}^{2} \bullet \mathrm{SpO} 2$ $99 \%$

Labs: • WBC 7.0 • RBC 4.68; Hb 133; Ht Na 141; K 4.3 Chol 7.02, HDL 1.28, LDL 4.83, TG 2.0 • Glucose 5.97

Physical examination: no signs of heart failure, poor blood pressure regulation, D3

ECG: sin. rhythm, heart rate $82 / \mathrm{min}, \mathrm{R} / \mathrm{S} \mathrm{V} 2$, micro q

Exercise capacity on day 1st: estimated by 6 minute walking test (due to poor prior physical activity) walking distance $320 \mathrm{~m}$, max BP 170/100 mmHg, heart rate 100/min

Three weeks in house cardiac rehabilitation program was created individually according to patient's age, past habits, co-morbidities, preferences and goals, with aim to:

1. Improve exercise capacity - 30 min moderate intensity aerobic activity 6 days a week

2. Perform additional heart test $-24 \mathrm{~h}$ ECG monitoring, BP monitoring, echocardiography

3. Optimize medical therapy:

a. oral anticoagulation: dabigatran replaced with warfarin

b. better blood pressure control: doses optimized and ramipril added

c. better lipid levels control: increase the dose

d. heart rate and rhythm control: amiodaron replaced with bisoprolol

4. Educate the patient: about anticoagulation including drug interactions and self-management, in depth knowledge on endocarditis prophylaxis, diet intake

Medication during in hospital staying:

1. Warfarin to reach target INR once daily (OD); INR results as follows $1.16 \ldots 2.14 \ldots 3.04$

2. Bisoprolol $5 \mathrm{mg}$ OD

3. Lercandipine $20 \mathrm{mg}$ OD

4. Rosuvastatin $20 \mathrm{mg}$ OD

5. Ramipril $5 \mathrm{mg}$ OD to achive target BP

Additional heart test were performed. The results were as follows:

1. During 24 hours of ECG recording the mean heart rate was $61 / \mathrm{min}$, minimal heart was $49 / \mathrm{min}$ at $2.00 \mathrm{am}$, maximal $88 / \mathrm{min}$ at 1.pm. No episodes of atrial fibrillation were recorded; there were 25 SVES and 2 VES.

2. Echocardiography exam: left ventricle was normal in diameter with preserved ejection fraction, mechani- cal valve on aortic position good in function, with gradient $22 / 12 \mathrm{mmHg}$. No signs of pericardial effusion.

Exercise capacity on day $21^{\text {st }}$ (estimated by 6 minute walking test): walking distance $420 \mathrm{~m}$, max BP $150 / 80 \mathrm{mmHg}$, heart rate $89 / \mathrm{min}$

\section{Discussion}

Aortic stenosis is the most common primary valve disease leading to surgery or catheter intervention in Europe and North America, with a growing prevalence due to the ageing population. In 2017 new guidelines were published by ESC and AHA/ACC ${ }^{4,5}$. Guidelines summarize and evaluate available evidence with the aim of assisting health professionals in selecting the best management strategies for an individual patient with a given condition. Guidelines and their recommendations should facilitate decision making of health professionals in their daily practice. However, the final decisions concerning an individual patient must be made by the responsible health professional(s) in consultation with the patient and caregiver as appropriate.

We aim to present the case that illustrate management after valve intervention, potential misunderstandings and correct new guidelines interpretation. General management should address effective control of modifiable risk factors. All patients require lifelong follow up by cardiologist after valve surgery.

Cardiac rehabilitation is indicated and performed by cardiologist in Western and Central Europe but not strongly in US. Cardiac rehabilitation (CR) programs should be available for all patients undergoing coronary artery surgery and valve surgery. CR should be according to individual risk profile, physical, psychological and social status assessed as part of preoperative medical history and examination. Furthermore, it should be appreciated that the clinical condition and concerns of surgical patients often relate to the surgical procedure itself (wound healing, co morbidities, complications and disabilities) ${ }^{6}$.

Our patient had postoperative atrial fibrillation (POAF) after isolated aortic valve replacement that may cause a concern. Recent studies indicated that POAF occures in $40 \%$ of operated patients, but according to data POAF is a risk factor for short-term morbidity and it is not associated with a higher rate of early or late mortality after isolated $\mathrm{AVR}^{7}$. Amiodaron in this case is not indicated in the long term therapy in patients with sinus rhythm. Bisoprolol was indicated instead. The 24 hours ECG monitoring showed good heart rate and rhythm control.

Exercise training was created according to clinical condition (poor BP control of patient at the beginning of the program), baseline exercise capacity (poor; estimated by $6 \mathrm{MWT}$-healthy adults range from 400 to $700 \mathrm{~m}$ ). After valve surgery exercise tolerance will take a significant time to recover compared to coronary artery surgery (after mitral valve replacement exercise tolerance is much lower than that after aortic valve replacement, particularly if there is residual pulmonary hypertension). Upper body training was indicated since chest was stabile (i.e. usually after 6 weeks or as advise by cardiosurgeon). Moderate intensity aerobic physical 
training composed of bicycling, walking and crossing over Nyllin steps, 6 times per week during 21 days. Exercise capacity of our patient was improved on discharged.

Regarding oral anticoagulants, guidelines from both sides of the world ${ }^{4,5}$ remain the same. Oral anticoagulation using a VKA is recommended lifelong for all patients with mechanical prosthesis! INR self-management is recommended to provide appropriate training and quality control. Target INR after mechanical prosthesis according the 2017 Guidelines will depend on prosthesis trombogenicity and patient related risk factors (mitral or tricuspid valve replacement, previous thromboembolism, atrial fibrillation, mitral stenosis any degrees, LVEF $<35 \%$ ). In our patient case (for St Jude prosthesis without risk factors) target INR is 3.0. During in patient CR program patient was educated in this term. Novel oral anticoagulants are not indicated in this patient population.

\section{Conclusion}

2017 ESC/EACTS Guidelines for the management of valvular heart diseases and 2017 AHA/ACC Focused Update of the 2014 AHA/ACC Guideline for the Management of Patients with Valvular Heart Disease in patients with mechanical valve remains the same indicating that anticoagulation with a VKA and INR monitoring is rec- ommended in patients with a mechanical prosthetic valve

\section{References}

1. Karlsson AK, Mattson B, Johansson M, Lidell E. Wellbeing in patients and relatives after open-heart surgery from the perspective of health care professionals. J of Clin Nur 2010;19:840-6

2. Hansen L, Winkel S, Kuhr J, Bader R, Bleese N, Riess FC. Factors influencing survival and postoperative quality of life after mitral valve reconstruction. European Journal of Cardio-Thoracic Surgery 2010;37:635-644.

3. Butchart EG, Gohlke-Bärwolf C, Antunes MJ, et al. Recommendations for the management of patients after heart valve surgery. Eur Heart J 2005;26:2463-2471

4. Baumgartner $\mathrm{H}$, et al: 2017 ESC/EACTS Guidelines for the management of valvular heart disease Eur Heart J 201; 38 (36): 2739-2791

5. Nishimura N, et al. 2017 AHA/ACC Focused Update of the 2014 AHA/ACC Guideline for the Management of Patients With Valvular Heart Disease. JACC 2017; 70 (2): 252-289

6. Piepoli $M$, et al. Secondary prevention in the clinical management of patients with cardiovascular diseases. Core components, standards and outcome measures for referral and delivery: a policy statement from the cardiac rehabilitation section of the European Association for Cardiovascular Prevention \& Rehabilitation. Endorsed by the Committee for Practice Guidelines of the European Society of Cardiology. Eur J Prev Cardiol. 2014; 21(6):664-81

7. Greenberg J, et al. Postoperative atrial fibrillation following cardiac surgery: a persistent complication. European Journal of Cardio-Thoracic Surgery 2017; 52(4): 665-672.

\section{Sažetak}

\section{Oralna antikoagulantna terapija posle izolovane zamene aortne valvule}

\section{Ivana Burazor}

Kardiologija, Institut za rehabilitaciju, Beograd, Srbija

Aorte stenoza je najčešća bolest valvula koja zahteva zamenu bilo operativnim lečenjem bilo transkateter intervencijom i to kako u Evropi tako i u Severnoj Americi, sa rastućom rasprostranjenošću zbog starenja stanovništva. Prikazali smo bolesnicu koja je upućena u naše kardiološko odelenje na tronedeljni program kardiološke rehabilitacije nakon izolovane zamene aortne valvule mehaničkom protezom. Kardiološka rehabilitacija ima za cilj da poboljša funkcionalni kapacitet aerobnim fizičkim treningom i optimizira terapiju sa posebnim osvrtom na upotrebu oralnih antikoagulanasa. Bolesnica je uspešno završila program, unapredila funkcionalni kapacitet i dostigla ciljne vrednosti INRa.

Izbor oralne antikoagulantne terapije nakon zamene zalistaka mehaničkim protezama prema preporukama i evropskog i američkog udruženja kardiologa je VKA, sa ciljnim INRom koji je definisan u odnosu na trombogenost mehaničkih proteza i prisustvo faktora rizika (mitralni ili trikuspidni veštački zalistak, prethodne tromboembolijske komplikacije, atrijalna fibrilacija, EF 35\%, mitralna stenoza).

Ključne reči: aortna stenoza, oralni antikoagulansi, kardiološka rehabilitacija 